\author{
Arkadiusz BEDNARZ ${ }^{1}$ \\ Michał KUŹNIAR ${ }^{2}$ \\ Evgeniy BOLTYNJUK ${ }^{3}$
}

\title{
Temperature distribution as a method of measuring crack length in fatigue tests of compressor blade
}

\begin{abstract}
In this paper the experimental results of fatigue analysis of the compressor blade were presented. Temperature distribution as a method of measuring crack length was considered. The blade with the V-notch (which simulates the foreign object damage) was entered into transverse vibration under resonance condition. During investigations both the amplitude of the blade tip displacement and also the crack length were monitored. At the same the pictures of time temperature distribution were taken. In the first part of the work the amplitude-frequency diagrams were obtained for different sizes of cracks. In the investigation, both a number of load cycles to crack initiation and dynamics of the crack growth in the compressor blade subjected to vibrations were determined. An additional original result of the work is the comparison of optically measured crack length and the dimension of the crack length taken from the picture. An important application will be the benefits of the method of measuring the length of the slot with a temperature distribution image. The results presented in this paper have theoretical and practical significance.
\end{abstract}

Keywords: crack propagation, notch, thermovision, turbine engine, adhesive friction, fatigue life, resonant vibrations

\section{Introduction}

The turbine aircraft engines have many parts and components subjected to various loads. One of these components are the compressor blades. Body forces (centrifugal) and forces from the flow of the air through the engine cause the elongation of the blade. Both type of forces cause bending. The blades have a low flexural resistance, due to the small thickness of the profile, they are also susceptible to mechanical vibrations. A special case of blade vibration was the resonance when they achieve a large amplitude and high stresses. The engine

\footnotetext{
1 Autor do korespondencji/corresponding author: Arkadiusz Bednarz, Rzeszow University of Technology, 8 Powstancow Warszawy Av., 35-959 Rzeszow, tel.: (+48) 17743 2348, e-mail: abednarz@ prz.edu.pl

${ }^{2}$ Michał Kuźniar, Rzeszow University of Technology, e-mail: mkuzniar@prz.edu.pl

${ }^{3}$ Evgeniy Boltynjuk, Saint Petersburg State University, e-mail:boltynjuk@gmail.com
} 
rotor during operational conditions has a high rotational speed and generates a negative pressure in the engine inlet. Sucked air flow often picks up foreign objects from the ground. As a result of a collision with such objects, various mechanical defects, located on the leading edge of the blade occur (fig. 1a). From the constructor's point of view the knowledge about the behavior of turbine engine blades in resonance and the progressive process of cracking of the blades is very important. To observe the initiation and propagation of cracks a thermographic method could be used. Assuming the heat generated in the areas of high displacements, the area of propagation of gap, may be tempted to test thermal imaging to characterize the behavior of the blades. This test was conducted in this study.

The problem of foreign object damage (FOD) was the subject of several investigations. In the first case the heat released in the vicinity of the crack was analyzed. This phenomenon was a result of adhesive friction between surfaces rubbing up against each other. Adhesion consists in the contact between the surfaces of the bodies as a result of the external forces acting between them. This field was caused by atomics forces around the contact surfaces. When this surfaces are rubbing against each other the forces of adhesion released heat energy that is dissipated. The friction was accompanied by energy of heat. Heat distribution in the body can be observed thanks to its emissivity. Emissivity was emitting energy as thermal radiation [4].

Infrared heat dissipation under fatigue crack propagation were a subject of several papers. Fedorova [1] present the description of the propagation of heat in the sample titanium (Ti-6Al-4V) subjected to cyclic loading. This work shows how a progressive fatigue crack change the temperature field around the gap. The study also proposes algorithms to describe the dissipation of heat in the sample and determine the stress intensity factor. The authors also found that the observed phenomena were non-linear. A method to measure a crack length in the material was described in work [5]. This method was based on thermographic detection. The sample was driven in motion with the help of ultra sound and an infrared camera recorded a change in the temperature field around the crack. The results of the test were compared to the FEM analysis in the Abaqus. Statistical analysis of damage to the blades of the turbine aircraft engine has been described in work [2]. The analysis was based on the test blades subjected to ultrasonic and then observed with the infrared camera. Papers $[1,2]$ present information about observation of crack propagation on a properly prepared plate with notch using a thermal camera. Vibration samples were ultrasonically induced. The results of the tests were compared with the FEM analysis. An overview of attempts to study the fatigue of the compressor blades on the inductor vibration was presented in $[6,7]$. Methodology of works $[6,7]$ is the basis of the analysis in this paper.

In the test the blade from the first stage of axial compressor from PZL-10W engine was used. The PZL-10W engine was mounted in a helicopter PZL W3 
Sokol. Alternative propeller version PZL-10S was used in the aircraft PZL M28 Bryza. This engine was produced and developed by PZL-WSK Rzeszow. The main objectives of the work are both the determination of a number of load cycles to the crack initiation and the temperature distribution with correlation to crack dimensions. An additional objective is also the dynamics of the crack growth in the blade with the notch created by machining.

a)

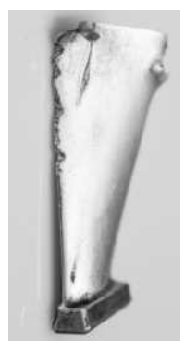

b)

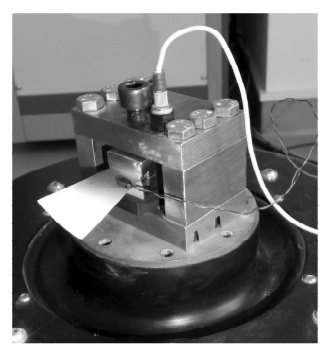

Fig. 1.View of a blade after a collision with an object sucked into the engine (a), the blade with a notch attached to the shaker head (b)

\section{Fatigue test in resonant condition}

The fatigue test of a compressor blade with V-notch created by machining was conducted. The blade was made of EI-961 steel $(0.11 \mathrm{C} ; 11 \mathrm{Cr} ; 1.5 \mathrm{Ni}, 1.6 \mathrm{~W}$; $0.18 \mathrm{~V} ; 0.35 \mathrm{Mo} ; 0.025 \mathrm{~S} ; 0.03 \mathrm{P}$ ) with the following properties (measured in the temperature of $20^{\circ} \mathrm{C}$ ): ultimate tensile strength is $900-1000 \mathrm{MPa}$, yield stress is 800-900 MPa, Young's modulus is $200 \mathrm{GPa}$, and Poisson's ratio value is 0.3 . Variable load was generated by a vibrating system Unholtz-Dickie TA-250. The compressor blade was attached to the shaker head. The view of a blade attached to the shaker head is shown in figure $1 \mathrm{~b}$. To measure the amplitude of the blade tip a laser vibrometer Polytec PSV-H400S was used. At the same time, as an alternative source of information, the amplitude was measured with an optical microscope. In the initial stage of studies, the resonant frequency of the blade (I mode) was determined. In the next step, the resonance fatigue tests were conducted, where a number of cycles and the length of the crack were controlled. In every stop, the amplitude-frequency characteristic was determined.

The crack length was defined as a distance between the point of crack origin and the end of the gap (fig. 2). Classical method to measure this dimension is based on fluorescent penetrant and UV light. Fluorescent penetration method was used to measure the size and length of the crack. In this method UV light and special fluid with fluorescent properties wad used. Fluorescent fluid was applied on the inner surface of the blade. The fluid after few transverse move of the blade was wiped off. UV light shows the places with where fluid. The cracks were observed in UV light. This method is not perfect. Each measurement requires stopping the attempts what may reduce the reliability of the results. As an 
alternative method of measuring the crack length, the picture of the temperature distribution on the blade was used (example is presented in figure 3). This image was taken with the VarioCAMhr head 640 infrared camera. The VarioCAM is a thermograph camera with sensitivity equal to $0.03 \mathrm{~K}$ and geometric resolution of $640 \times 480$ pixels. Adhesive friction between both parts of newly established faces of crack causes the release of energy around the gap. This energy was monitored as a local temperature gradient (fig. 3).

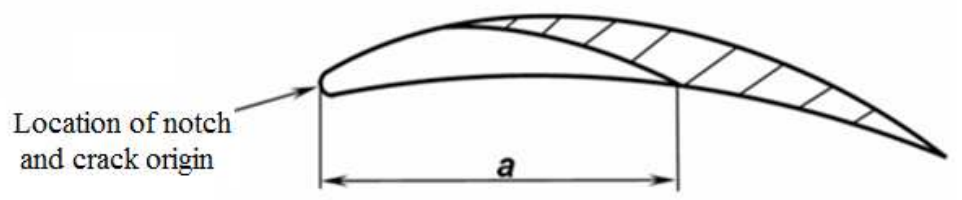

Fig. 2. Sketch of the broken blades with defined length (a) of the crack

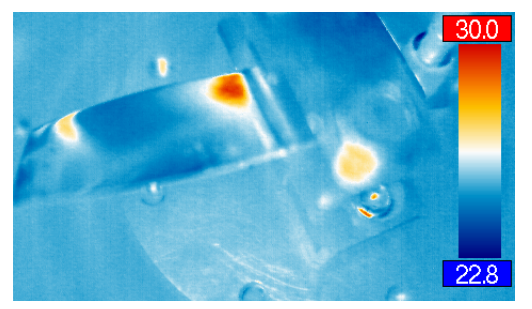

Fig. 3. View of temperature distribution image taken with the VarioCAM

To prepare the picture of temperature distribution some images of processing algorithms were used. The view of the crack was assembled from two main part. The first part was adhesive friction and the heat connected. The second part was the energy released from cracking processes. The heat caused by adhesive friction looks like straight lines. The lines were strictly connected with the edge of the gap. The energy released from cracking processes were observed on temperature distribution image. This field of energy have a round shape (connected with stress distribution around the crack tip).

\section{Results}

The blade used in the experimental test has the same metrical parameters of the notch like in works $[6,7]$. In every case, the distance between the notch and the foot of the blade is equal to $3 \mathrm{~mm}$ (fig. 4). In the whole test the amplitude of displacement is equal to $\mathrm{A}=1.8 \mathrm{~mm}$. 


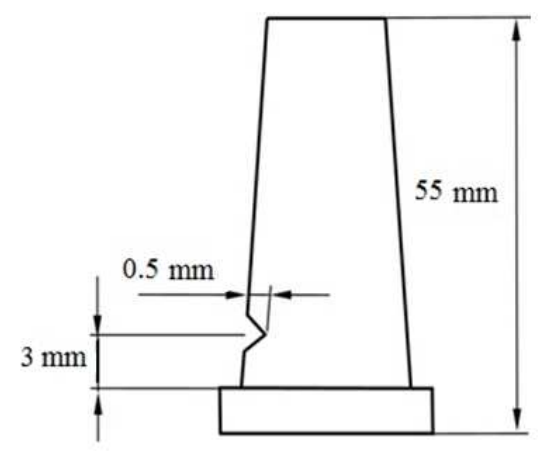

Fig. 4. Dimensions of the investigated object

Based on the obtained results was prepared table 1 with the information about a number of cycles to damage blade. In the first column there is initial frequency with the test begin. Second column contents, information about final frequency of the test. The rate of change of frequency were determined as a change of frequency during the test and time of the test. Every part of the investigation has the same parameters such as intensity of excitation and amplitude of the blade tip. The main differences on the crack length (parameter a) were observed. Additionally, a table with amplitude and resonant frequency for a subsequent part of the test was prepared. The information about a frequency and amplitude (from a amplitude-frequency characteristics) is were shown in table 2. An intensity of excitation was the same in every case of the study and it was equal to $1 \mathrm{~g}$. Unit $\mathrm{g}$ is the gravitational acceleration and it is equal to $9.81 \mathrm{~m} / \mathrm{s}^{2}$.

The partial number of load cycles is the information about that how many cycles take place during this part of the test. The total number of cycles is the information about the whole number of cycles from the beginning of this test (sum of partial cycles). The total number of cycles (crack propagation CP) is similar to earlier quantity but it starts impart after crack initiation appear. Crack initiation was determined as the point when the crack length achieves the dimension equal to $1 \mathrm{~mm}$. In figures 5 and 6 load history are presented. The figure 5 shows the whole crack propagation tests. When the crack length achieves 12 $\mathrm{mm}$, test becomes unstable. This part of the investigation has dynamic behavior. When tip of the blade achieves the local maximum, a brittle crack was observed. The amplitude-frequency characteristics move toward the lower resonant frequency. With brittle cracking a lot of energy was released. The faster the process of cracking that will be more visible on the distribution of temperature. The round shape of temperature distribution was observed only when crack increased. If the crack propagation process is stopped, $t$ only the heat from adhesive friction will be observed in the image of temperature distribution. This was observed between the crack length from 1 to $10 \mathrm{~mm}$. Figure 6 shows amplitudes in this part of the investigation. The phenomenon of emission of the heat was observed when the amplitude was constant. 
Table 1. Control parameters of vibration system and results of the fatigue test of the blade $(\mathrm{A}=1.8 \mathrm{~mm})$

\begin{tabular}{|c|c|c|c|c|c|c|c|c|c|}
\hline 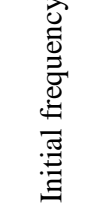 & 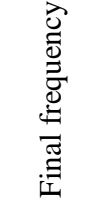 & 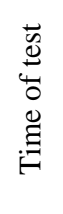 & 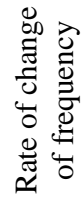 & 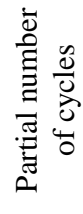 & 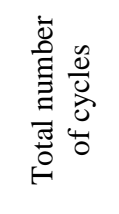 & 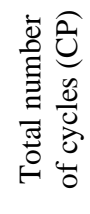 & 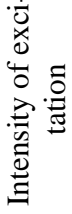 & 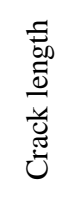 & 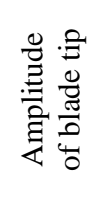 \\
\hline $\begin{array}{c}\mathrm{F}_{\text {init }} \\
\mathrm{Hz}\end{array}$ & $\begin{array}{l}\mathrm{F}_{\text {fin }} \\
\mathrm{Hz}\end{array}$ & $\mathrm{s}$ & $\begin{array}{c}\mathrm{dF} / \mathrm{dt} \\
\mathrm{Hz} / \mathrm{s} \\
\end{array}$ & $\begin{array}{r}\mathrm{N}_{\text {part }} \\
\times 10^{6} \\
\end{array}$ & $\mathrm{~N} \times 10^{6}$ & $\begin{array}{r}\mathrm{N}_{\mathrm{cp}} \\
\times 10^{6} \\
\end{array}$ & $\mathrm{~g}$ & $\begin{array}{c}\mathrm{a} \\
\mathrm{mm}\end{array}$ & $\begin{array}{c}\mathrm{A} \\
\mathrm{mm} \\
\end{array}$ \\
\hline 817.59 & 813.89 & 177 & 0.020 & 0.144 & 0.144 & 0 & 15 & 1 & 1.8 \\
\hline 813.6 & 803 & 86 & 0.123 & 0.07 & 0.214 & 0.069 & 15 & 4.2 & 1.6 \\
\hline 803.03 & 780.53 & 105 & 0.214 & 0.083 & 0.297 & 0.153 & 15 & 6.8 & 1.8 \\
\hline 777.44 & 751.44 & 41 & 0.634 & 0.031 & 0.328 & 0.184 & 15 & 10 & 1.8 \\
\hline 750 & 705 & 28 & 1.607 & 0.02 & 0.348 & 0.204 & 15 & 11.6 & 1.8 \\
\hline 700 & 500 & 184 & 1.087 & 0.110 & 0.459 & 0.315 & 15 & 14.7 & $1-1.5$ \\
\hline 500 & 200 & 160 & 1.875 & 0.056 & 0.515 & 0.371 & 15 & 17.2 & $1-1.5$ \\
\hline
\end{tabular}

Table 2. Result of resonant vibration peaks from amplitude-frequency characteristics for different crack length

\begin{tabular}{|c|c|c|c|}
\hline $\begin{array}{c}\text { Resonant fre- } \\
\text { quency }\end{array}$ & $\begin{array}{c}\text { Amplitude of } \\
\text { displacement }\end{array}$ & Crack length & $\begin{array}{c}\text { Intensity } \\
\text { of excitation }\end{array}$ \\
\hline $\mathrm{F}_{\text {rez }}, \mathrm{Hz}$ & $\mathrm{A}, \mathrm{mm}$ & $\mathrm{a}, \mathrm{mm}$ & $\mathrm{g}$ \\
\hline 822.4 & 0.35 & 0 & 1 \\
\hline 816.6 & 0.28 & 1.0 & 1 \\
\hline 804.0 & 0.28 & 4.2 & 1 \\
\hline 785.4 & 0.23 & 6.8 & 1 \\
\hline 769.2 & 0.11 & 10.0 & 1 \\
\hline 711.4 & 0.054 & 11.6 & 1 \\
\hline 492.2 & 0.26 & 14.7 & 1 \\
\hline 178.6 & 0.39 & 17.2 & \\
\hline
\end{tabular}

The plot of resonant frequency as the function of the crack length is shown in figure 7. The crack appears when the resonant frequency decreases at about $0.7 \%$. The resonant frequency slowly decreases with the small crack length (from 0 to $10 \mathrm{~mm}$ ). The change in the frequency was lower than $7 \%$. When the crack length is longer than $10 \mathrm{~mm}$, negative gradient of change of resonant vibration increases. The destruction of the blade finishes this phenomenon.

The crack length was connected with amplitude achieved in resonant condition. Amplitude-frequency characteristics for different crack sizes were shown in figure 8 . When the crack length increases, resonant frequency decreases and amplitude achieved in the resonant condition decreases. This phenomenon was observed for the crack dimension bigger than $60 \%$ of the whole blade length. After this amplitude start increasing. An increase of the crack has an influence 
on cross section area in the plane parallel to the foot of the blade. Smaller cross section area reduces the stiffness of the element.

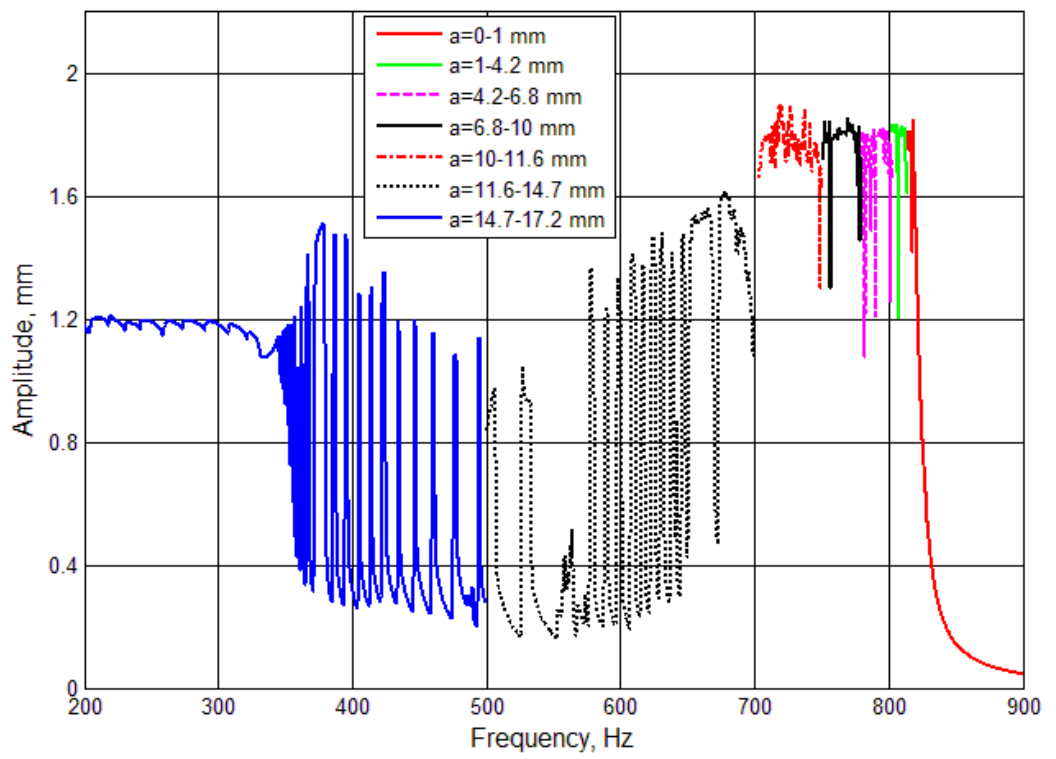

Fig. 5. The crack growth process

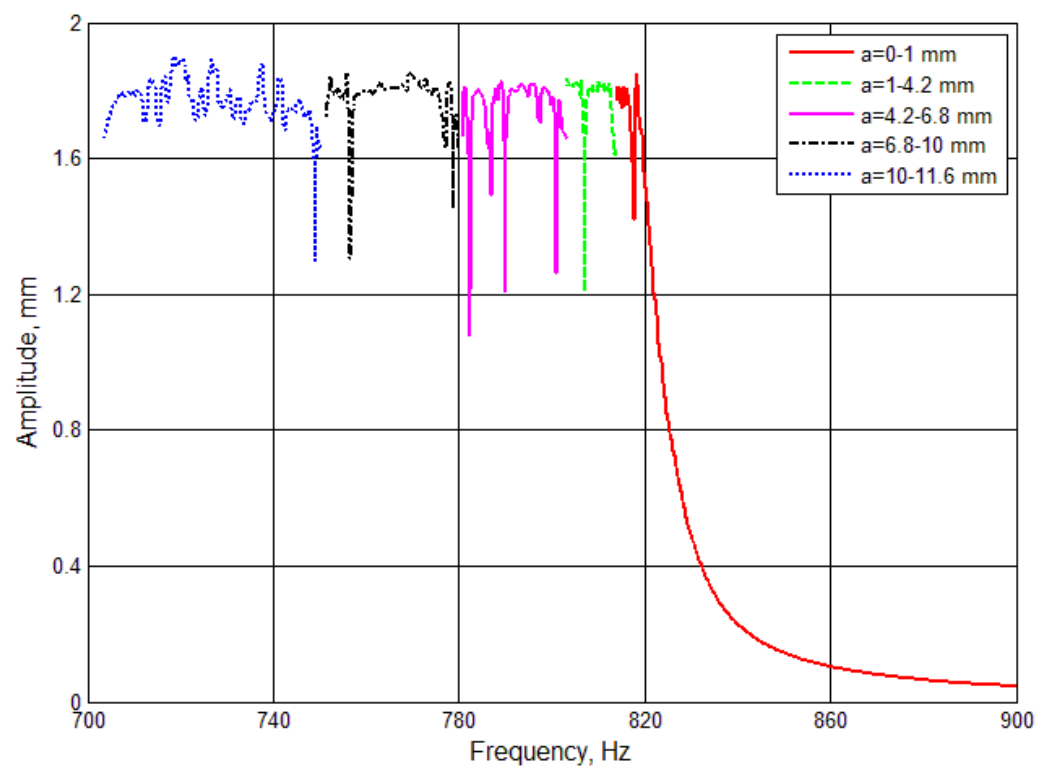

Fig. 6. Crack growth from 0 to $11.6 \mathrm{~mm}$ 


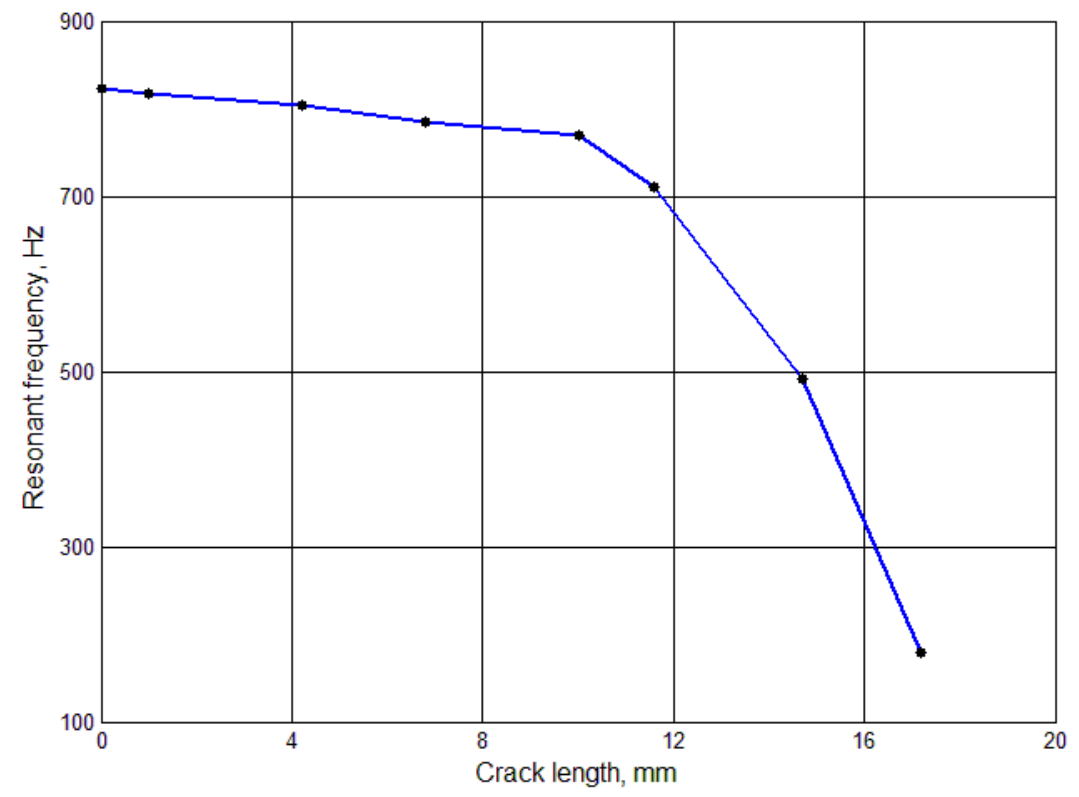

Fig. 7. Plot of resonant frequency as a function of crack length

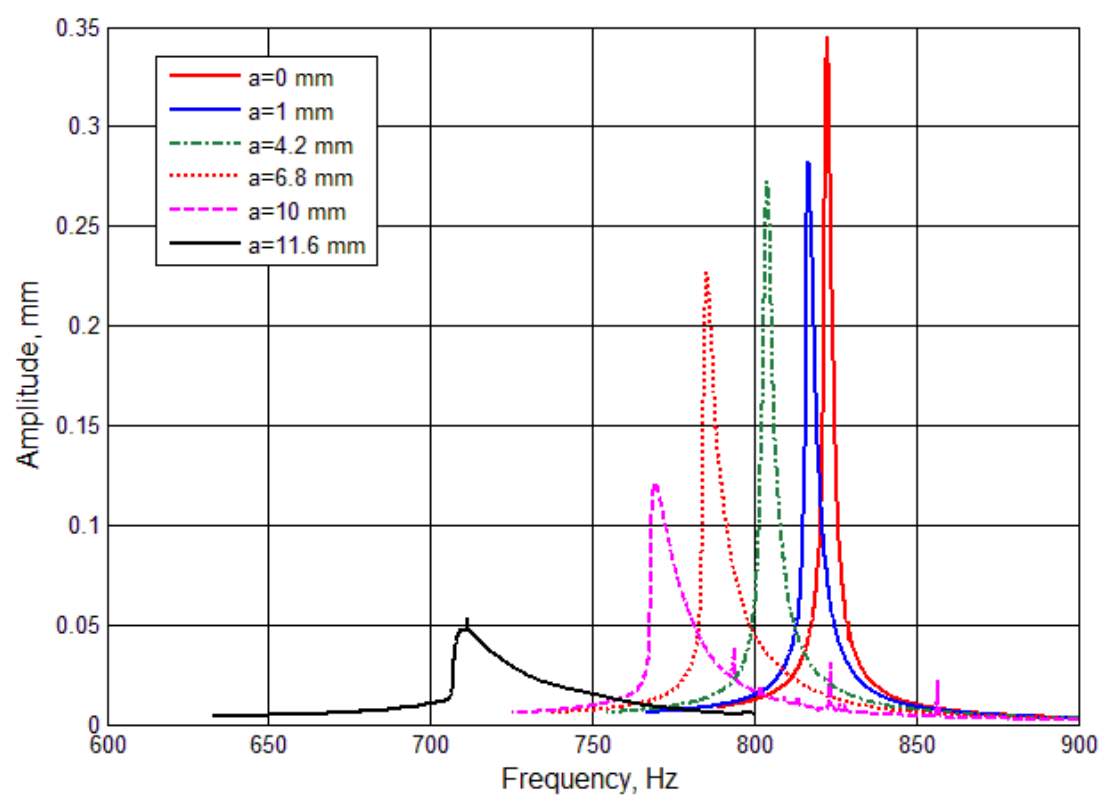

Fig. 8. Amplitude-frequency characteristics of the blade for different crack sizes (intensity of excitation is equal to $1 \mathrm{~g}$ ) 
The results obtained from optical measuring of the crack length are compared with results from temperature distribution. To image processing two methods were used. The first of method was based on MATLAB algorithm. The results from this transformation were presented in figure 9.
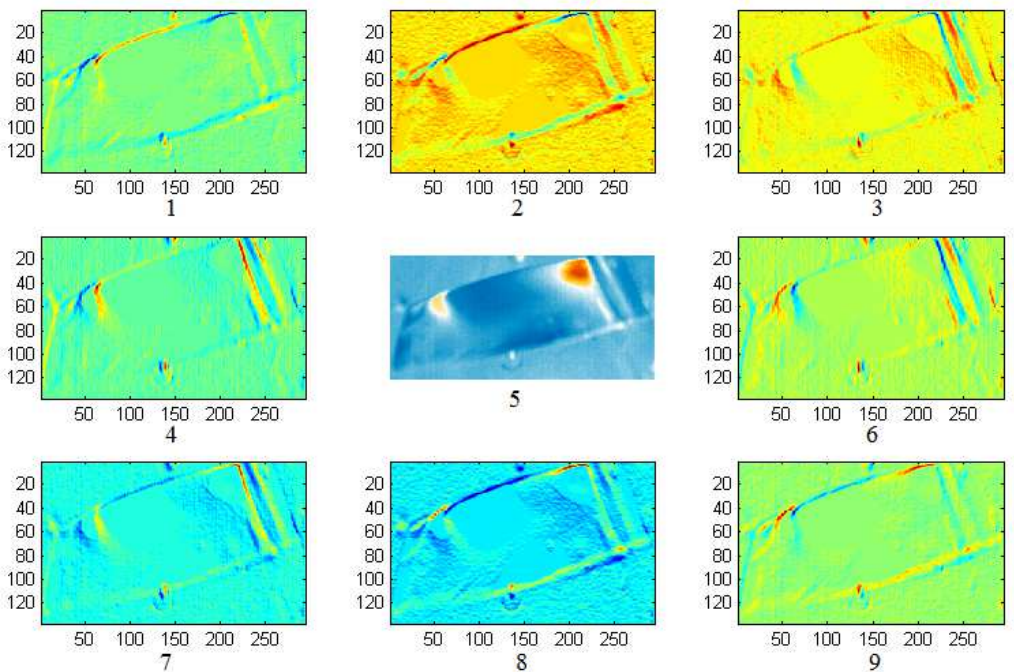

Fig. 9. Temperature distribution image for blade with crack equal to $1 \mathrm{~mm}$ after image processing (edge detection)

Based on this algorithm it is possible to detect edge (in the image view) in different direction. The edge in the picture was defined as a change of color between next pixels. This code was used to prepare images for the crack length equal to $10 \mathrm{~mm}$. The best results (fig. 9) were observed on window 4 and 6, were the code scans the image in search of edge in vertical direction. In the second method for edge detection Photoshop software was used. The results for different crack lengths were shown in figures 10-13. Figure 10 shows temperature distribution after crack initiation (dimension of the crack is $1 \mathrm{~mm}$ ). An increase in the length of the gap causes a change in temperature distribution(figs. 11 and 12). The shape of the temperature in the vicinity of the notch shows what exactly happened. If it has round shape, the cracking process will take place (see example in figure 13).

Measuring method indicates some differences. More accurate results were obtained using classical (optical) method of measuring crack length. The dimensions of cracks obtained from temperature distribution images have measurement error about $1 \mathrm{~mm}$. On the other hand the proposed method does not introduce errors resulting from the retention test. 


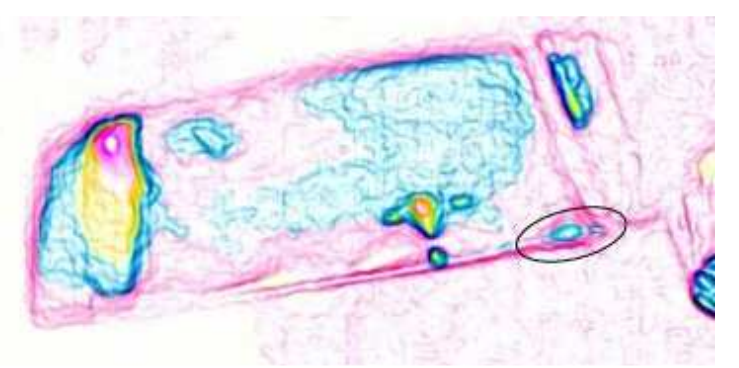

Fig.10. Temperature distribution image for blade with crack equal to $1 \mathrm{~mm}$ after image processing (edge detection)

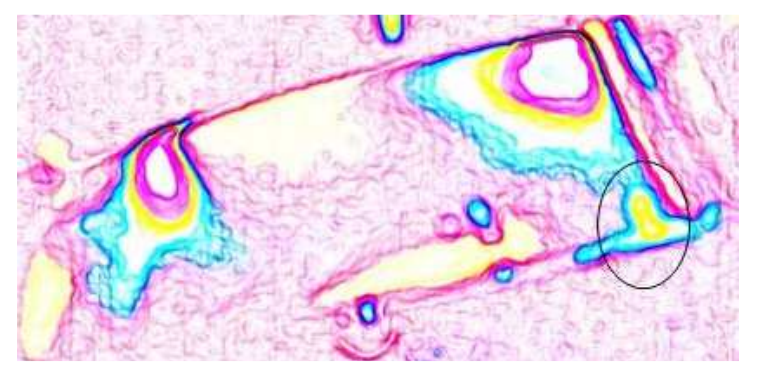

Fig. 11. Temperature distribution image for blade with crack equal to $4.2 \mathrm{~mm}$ after image processing (edge detection)

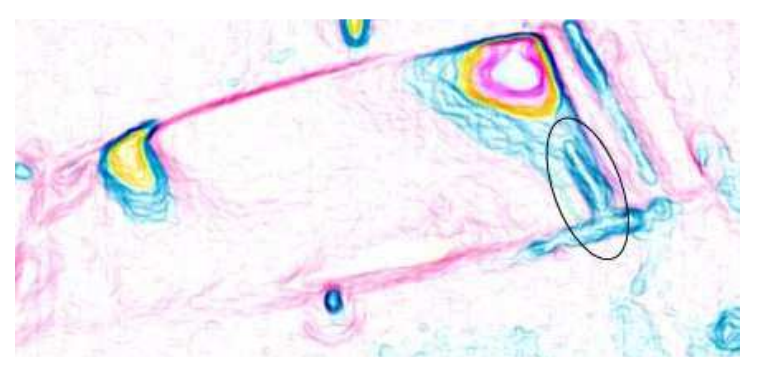

Fig. 12. Temperature distribution image for blade with crack equal to $10 \mathrm{~mm}$ after image processing (edge detection)

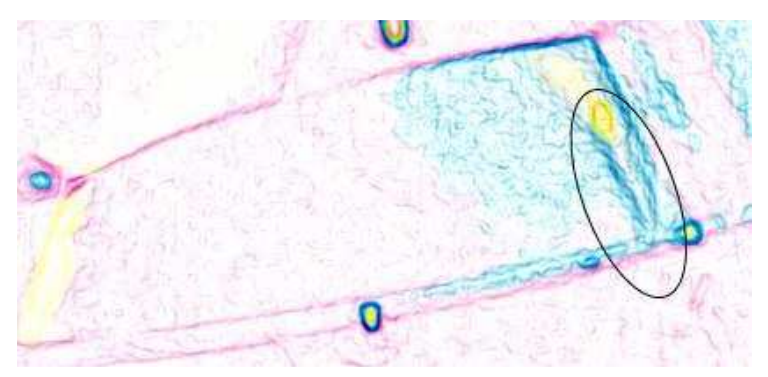

Fig. 13. Temperature distribution image for blade with crack equal to $11.6 \mathrm{~mm}$ after image processing (edge detection) 


\section{Summary}

For the blade with amplitude of displacement equal to $1.8 \mathrm{~mm}$, the crack initiates after $144 \times 10^{3}$ load cycles. The difference between the blade with the crack length $\mathrm{a}=0 \mathrm{~mm}$ and $\mathrm{a}=6.8 \mathrm{~mm}$ is almost $35 \%$ for a change of resonant frequency and for amplitude is more than $6 \%$. The difference between the results for $\mathrm{a}=0$ and $\mathrm{a}=10 \mathrm{~mm}$ are $7 \%$ for resonant frequency and $68 \%$ for amplitude. Critical point was reached when the crack length achieved the value about 10 $\mathrm{mm}$. For the crack length from 0 to $10 \mathrm{~mm}$, resonant frequency decreases at about $53 \mathrm{~Hz}$. In the next part of the diagram, resonant frequency decreases faster. The crack dimension measured on temperature distribution image have accuracy equal to $1 \mathrm{~mm}$. This apparatus is good for a test when measured dimension is longer than $2-3 \mathrm{~mm}$.

Better results can be obtained when a camera with higher resolution and higher sensitivity is used. Presented method could be used as a nondestructive method to measure the crack dimensions in the fatigue test. Temperature distribution image eliminates the most important disadvantage of the classical method that is the need to stop test to apply penetrant and measure the crack.

\section{Acknowledgement}

The research leading to these results has received funding from the People Programme (Marie Curie International Research Staff Exchange) of the European Union's Seventh Framework Programme FP7/2007-2013/ under REA grant agreement $n^{\circ}$ PIRSES-GA2013-610547.

\section{References}

[1] Fedorova A.Yu., Bannikov M.V, Plekhov O.A.: Infrared thermography study of the fatigue crack propagation, Fracture Structural Integrity, 21 (2012) 46-54.

[2] Gao C., Meeker W.Q, Mayton D.: Detecting cracks in air craft engine fan blades using vibrothermography nondestructive evaluation, Reliability Eng. System Safety,131 (2014) 229-235.

[3] Hebda M., Wachal A.: Trybologia, WNT, Warszawa 1980.

[4] Holman J.P.: Heat Transfer -Tenth edition, McGraw-Hill, New York 2010.

[5] Saboktakin Rizi A., Hedayatrasa S., Maldague X., Vukhanh T.: FEM modeling of ultrasonic vibrothermography of a damaged plate and qualitative study of heating mechanisms, Infrared Physics Technol., 61 (2013) 101-110.

[6] Witek L., Bednarz A., Stachowicz F.: Fatigue analysis of compressor blade with simulated foreign object damage, Eng. Failure Analysis, 58 (2015) 229-237.

[7] Witek L. Bednarz A.: Numeryczno-eksperymentalna analiza naprężeń oraz drgań własnych łopatki sprężarki silnika turbinowego, Logistyka, 6 (2014) 11177-11186. 


\section{ROZKŁAD TEMPERATURY JAKO METODA POMIARU DŁUGOŚCI PĘKNIĘCIA W TESTACH ZMĘCZENIOWYCH LOPATEK SPRĘŻARKI}

\section{Streszczenie}

W niniejszej pracy przeprowadzono eksperymentalną analizę zmęczeniową łopatki sprężarki lotniczego silnika turbinowego. Rozkład temperatur na łopatce wykorzystano do określenia długości powstałej w trakcie badań szczeliny zmęczeniowej. Łopatka z karbem symulującym uszkodzenie obcym obiektem została poddana drganiom poprzecznym wstanie rezonansu. Podczas badań zarówno amplituda przemieszczenia wierzchołka ostrza, a także długość pęknięcia były monitorowane. W tym samym czasie wykonano kamerą termowizyjną zdjęcia rozkład temperatury. W pierwszej fazie pracy wykresy amplitudowo-częstotliwościowe uzyskano dla różnej wielkości pęknięć. Określono liczbę cykli obciążeń do inicjacji pęknięć, a także dynamikę wzrostu pęknięć w łopatce sprężarki narażonej na drgania. Dodatkowym efektem pracy jest porównanie długości szczelin zmierzonych bezpośrednio na badanej łopatce jak i na obrazie z rozkładami temperatury wokół pęknięcia. Przedstawiono zalety metody pomiaru długości szczeliny z wykorzystaniem zdjęć z kamery termowizyjnej. Wyniki przedstawione w niniejszym artykule mają wartość teoretyczną i praktyczną.

Słowa kluczowe: propagacja pęknięć, szczelina, termowizja, silnik turbinowy, tarcie adhezyjne, trwałość zmęczeniowa, wibracje rezonansowe

DOI: $10.7862 / \mathrm{rm} .2016 .1$

Otrzymano/received: $19.01 .2016 r$.

Zaakceptowano/accepted: 21.03.2016 $r$. 